\title{
Zinc and Boron Application Improves Yield, Yield Components and Gross Returns of Mungbean (Vigna radiata L.)
}

\author{
${ }^{a, b}$ Aniqa Mubeen, ${ }^{a, c}$ Muhammad Tariq Saeed ${ }^{*}$ aMuhammad Farrukh Saleem, ${ }^{a}$ Muhammad Ashfaq Wahid \\ a Department of Agronomy, University of Agriculture, Faisalabad 38040, Pakistan. \\ b Plant Physiology Section, Agronomic Research Institute, Faisalabad, Ayub Agricultural Research Institute, Faisalabad, Pakistan. \\ c Department of Agriculture, Hazara University, Mansehra, 21300 Khyber Pakhtunkhwa, Pakistan.
}

Corresponding Author: Muhammad Tariq Saeed,Email: mtsuaf@gmail.com

\section{ART ICLE INFO}

\section{Article History}

Received: August 10, 2020

Revised: October 20, 2020

Accepted: October 26, 2020

\section{Keywords \\ Green gram \\ Minerals \\ $\mathrm{N}$-fixation \\ Protein \\ Pulse crop}

Abbreviations
Boron (B)
Zinc (Zn)
University of Agriculture,
Faisalabad (UAF)
Di-ammonium phosphate
(DAP)
Sulphate of potash (SOP)
Nuclear Institute for
Agriculture and Biology
(NIAB)

\section{A B S T R A C T}

Among pulses, mungbean is being considered as valuable cash crop in Pakistan but its productivity is under stress due to various agronomic and nutrient related management factors. Current study was planned to assess the interactive effect of soil applied zinc (Zn) and boron (B) under both field and pot managed conditions. Experiment was conducted at the Agronomic Research Area, Department of Agronomy, University of Agriculture, Faisalabad which is located at $31^{\circ}$ North latitude and $73^{\circ}$ East longitude with an altitude of 185 meters above sea level. The experimental treatments were comprised of three $\mathrm{Zn}\left(0,2\right.$ and $\left.4 \mathrm{~kg} \mathrm{Zn} \mathrm{ha}^{-1}\right)$ and three $\mathrm{B}\left(0,2\right.$ and $\left.4 \mathrm{~kg} \mathrm{Zn} \mathrm{ha}^{-1}\right)$ rates which were applied in nine combinations viz., $\mathrm{B}_{0} \mathrm{Zn}_{0}$, $\mathrm{B}_{0} \mathrm{Zn}_{2}, \mathrm{~B}_{0} \mathrm{Zn}_{4}, \mathrm{~B}_{2} \mathrm{Zn}_{0}, \mathrm{~B}_{2} \mathrm{Zn}_{2}, \mathrm{~B}_{2} \mathrm{Zn}_{4}, \mathrm{~B}_{4} \mathrm{Zn}_{0}, \mathrm{~B}_{4} \mathrm{Zn}_{2}, \mathrm{~B}_{4} \mathrm{Zn}_{4}$. Results revealed that, variations between field and pot trials as treatment $B_{0} Z_{n}$ helped to increase plant height (60.66 $\mathrm{cm})$ and pod length $(10.17 \mathrm{~cm})$ in field trials while $\mathrm{B}_{2} \mathrm{Zn}_{4}$ positively affected plant height ( $56.8 \mathrm{~cm} \& 27 \mathrm{~cm}$ ), number of pods per plant (38.78 \& 20.66), pod length (9.28 $\mathrm{cm} \& 10.18 \mathrm{~cm})$, number of nodules (12.56 \& 9) and seed yield (1402 $\mathrm{t} \mathrm{ha}^{-1} \& 6.42 \mathrm{~g}$ plant $^{-1}$ ) in both field and pot trials, respectively. Moreover, $\mathrm{B}_{2} \mathrm{Zn}_{4}$ treatment also improved the number of pod bearing branches per plant (9.03) and number of seeds per pod (8.36) in field trial as compared to control and other set of treatments. Yield related attributes were also significant with $\mathrm{B}_{2} \mathrm{Zn}_{2}$ treatment under field conditions but negative effects in terms of low yield and its related attributes were witnessed with other set of treatments under both experimental conditions. Based on this data, $\mathrm{B}_{2} \mathrm{Zn}_{4}$ is recommended to farmers facing soil related $\mathrm{Zn}$ and B deficiency problems, to get maximum economic returns of mungbean.

\section{INTRODUCTION}

Pulses are the rich source of high-quality protein in Pakistan. Different pulses are grown in Pakistan such as cowpea, chickpea, lentil, mungbean and black gram (Ali and Abedullah, 1998; Rani et al., 2014). Among these, mungbean (Vigna radiata L.) is an important conventional pulse grown in Pakistan, also known as green gram and a major component of many cropping systems. Among pulses, it ranks third in Pakistan and is a source of low priced protein thus a large population section relies on it (Usman et al., 2007). Green gram seeds are rich source of amino acids and protein thus serve as valued protein entity for human consumption. This crop is primarily grown for its valuable edible seeds and commonly eaten as boiled or fried food. Sprouts and pods of green gram are used as vegetable and are good source 
of minerals and vitamins. This legume crop enriched with valuable mineral contents (Sandberg, 2002) such as carbohydrates (59.9\%), protein (24.5\%), fiber (3-4.5\%), fat (1-3\%) and ash (4-4.5\%). One hundred gram of split grains contains calcium (75 mg), $\beta$-carotene $(49 \mathrm{mg}$ ) and iron (8.5 mg) (Afzal et al., 2004). The leaves, husks and stalks of mungbean are used as fodder and whole plants can be ploughed under as green manure for improving soil fertility. Moreover, this crop fixes atmospheric $\mathrm{N}$ through establishing a symbiotic relationship with specific bacteria by forming root nodules thus improves the natural soil fertility (Mahmood and Athar, 2008; Mandal et al., 2009).

Green gram is a short duration, drought tolerant crop which is sown twice in a year both as spring and autumn crop. In 2018, area under mungbean cultivation was 186.7 thousand hectares with production of 132.7 thousand tons (Govt. of Pakistan, 2020). It can usually be grown on marginal lands in Pakistan. As compared to other countries, there is a wide gap (70\%) between actual and potential yield of green gram in Pakistan due to poor soil fertility and low yielding varieties. As no other crop is as economical as mungbean, so a significant part of cultivated area has almost been fixed for its cultivation. The area can be enlarged by planting green gram as mix or inter crop or planting it on available fallow land after harvesting of wheat(Khattak et al., 2003; Khattak et al., 2004). The yield and yield components of mungbean can be improved by using high yielding varieties and balanced fertilization (Yin et al., 2018).

Food production and fertilizer application are inseparably linked. Micronutrients are just as important for plant nutrition as macronutrients. Importance of these mineral nutrients has increased in recent years due to use of high yielding cultivars and exhaustive cropping systems. Moreover, the climatic as well as calcareous soil conditions of Pakistan (Rashid and Ryan, 2008) are the major causes for the micronutrients deficiency, particularly of Zn (Broadley et al., 2012). Micronutrients are crucial and have promising effects on plant growth and development (Nawab et al., 2011) however, they are required in small quantities as compared to macronutrients. Among micronutrients, $\mathrm{Zn}$ scarcity is most critical in crops and human beings (Hotz and Brown, 2004). Currently Zn deficiency is listed as major risk factor for human health and death globally (WHO, 2002). In Pakistan, children and women suffer from $\mathrm{Zn}$ deficiency of $30-40 \%$ and $40-50 \%$, respectively, due to consumption of cereal based diet lacking in Zn that also renders its low bioavailability in human body (Hafeez et al., 2013). This is a third most severe crop nutrition disorder in Pakistan after nitrogen $(\mathrm{N})$ and phosphorus (P) (Alloway, 2008). In plants, several enzymes require $\mathrm{Zn}$ to catalyze the metabolic reactions (Vallee and Auld, 1990) such as photosynthesis, nitrogen metabolism and resistance against biotic and abiotic stresses (Alloway, 2004). Zn plays pivotal role in growth, cell and tissue differentiation (Osendarp et al., 2003). Insufficient supply of Zn can affect crop yield and quality (Vallee and Falchuk, 1993; Sasode, 2008) because it is required for hormones production, elongation of inter-nodal distance, leaf area enhancement, phosphorus utilization, plant growth regulation and in ensuring timely plants maturity (Nasiri et al., 2011).

In addition, boron (B) supply is essential for all vascular plants, hence its deficiency or excess harms several metabolic and physiological functions (Reid, 2007; Camacho et al., 2008). This non-metal element (Gupta, 2007) plays vital role in cell division, pod and seed formation. Its limitation leads to prominent reduction in growth, nodulation, yield, viability and vigor in legumes (Quddus et al., 2011). It also controls the carbohydrate translocation and water absorption in plants, thus economic yield of legumes is hampered when supplied with limited quantity of B (Raj, 1985; Ross et al., 2006). Keeping in view the adverse effects of limited micronutrients availability at different growth and development stages in legumes, authors have planned to study the interactive effects of $\mathrm{Zn}$ and $\mathrm{B}$ on mungbean under field and pot grown (controlled) conditions. The objective of this study was to evaluate the proper dose of soil applied $\mathrm{Zn}$ and $\mathrm{B}$ in combination to improve the agronomic performance and net income benefits in mungbean crop.

\section{MATERIALS AND METHODS}

\section{Crop husbandry practices}

A field trial on $4^{\text {th }}$ April, 2012 was conducted in 2012 at the Agronomic research area, University of Agriculture, Faisalabad (UAF), Faisalabad-Pakistan and a pot trial was also conducted in wire house at similar site on $29^{\text {th }}$ March, 2012. The climate of this region is semi-arid and sub-tropical. Experimental area is located at $73.06^{\circ}$ East longitude, $31.27^{\circ}$ North latitude and at an altitude of 184.4 meters above sea level. The seed of mungbean variety NIAB Mung-11 (NM-11) was obtained from Nuclear Institute for Agriculture and Biology, Faisalabad, 
Pakistan. The field experiment was laid out in randomized completely block design with three replications while pot experiment was carried out in complete randomized design by using five replications.

Before sowing of crop, the composite and representative soil samples were collected from experimental area at 15$30 \mathrm{~cm}$ depth with soil auger. Soil analysis was carried out in Environmental Sciences Lab, Institute of soil and environmental science, UAF. Soil samples were analyzed for various physical and chemical properties and details are listed in the Table 1. All weather data of crop season were obtained from Agro-meteorological observatory, Department of Crop Physiology, UAF, situated $200 \mathrm{~m}$ away from experimental site. Data about monthly averages of minimum and maximum temperature, relative humidity, rainfall, pan evaporation and sunshine hours are depicted in the Table 2.

Table 1. Effect of zinc sulphate and boric acid application on benefit cost ratio (BCR) of mungbean.

\begin{tabular}{lcc}
\hline Treatments & Net Income $\left(\right.$ Rs. ha $\left.{ }^{-1}\right)$ & $\begin{array}{c}\text { Benefit Cost } \\
\text { Ratio }\end{array}$ \\
\hline $\mathrm{B}_{0} \mathrm{Zn}_{0}$ & 38537 & 1.71 \\
$\mathrm{~B}_{0} \mathrm{Zn}_{2}$ & 53651 & 1.99 \\
$\mathrm{~B}_{0} \mathrm{Zn}_{4}$ & 46449 & 1.85 \\
$\mathrm{~B}_{2} \mathrm{Zn}_{0}$ & 52090 & 1.96 \\
$\mathrm{~B}_{2} \mathrm{Zn}_{2}$ & 62162 & 2.14 \\
$\mathrm{~B}_{2} \mathrm{Zn}_{4}$ & 68477 & 2.24 \\
$\mathrm{~B}_{4} \mathrm{Zn}_{0}$ & 40705 & 1.74 \\
$\mathrm{~B}_{4} \mathrm{Zn}_{2}$ & 56030 & 2.01 \\
$\mathrm{~B}_{4} \mathrm{Zn}_{4}$ & 57918 & 2.04 \\
\hline
\end{tabular}

Table 2. Results of physico-chemical analysis of soil.

\begin{tabular}{lcc}
\hline Determination & Unit & Value obtained \\
\hline Sand & $\%$ & 33.78 \\
Silt & $\%$ & 34.12 \\
Clay & $\%$ & 32.23 \\
EC & $\mathrm{dSm}^{-1}$ & 1.2 \\
$\mathrm{pH}$ & --- & 8.2 \\
Organic matter & $\%$ & 0.92 \\
Total N & $\%$ & 0.058 \\
Available phosphorous & $\mathrm{ppm}$ & 8.9 \\
Available K & $\mathrm{ppm}$ & 166 \\
Zinc & $\mathrm{ppm}$ & 0.80 \\
Boron & $\mathrm{ppm}$ & 0.49 \\
\hline
\end{tabular}

After pre-soaking irrigation, soil was left to achieve the proper moisture level and seed bed was prepared by cultivating the soil 2-3 times with tractor mounted cultivator followed by planking. Mungbean variety NM11 was sown on $4^{\text {th }}$ April, 2012. Sowing was done with the help of single row hand drill at $30 \mathrm{~cm}$ spaced rows using seed rate of $30 \mathrm{~kg} / \mathrm{ha}$ while ten seeds were sown in each pot. Fertilizers were applied at the rate of 23, 58 and 30 $\mathrm{kg} / \mathrm{ha} \mathrm{N}, \mathrm{P}_{2} \mathrm{O}_{5}$ and $\mathrm{K}_{2} \mathrm{O}$, respectively. All of phosphorus, potash and half of the nitrogen were applied at the time of sowing in the form of DAP, SOP and Urea, respectively. Remaining half $\mathrm{N}$ was applied at first irrigation.

Thinning was done before first irrigation to maintain the plant to plant distance of $10 \mathrm{~cm}$ in field. Thinning was done 10 days after emergence of seedlings to maintain 30 plants per plot in filed trial and 3 plants were maintained per pot. Crop was kept weed free by hoeing twice (i.e, first before $1^{\text {st }}$ irrigation and second after first irrigation) to avoid weed crop competition. Insect pests were kept under threshold level through chemical control. Under field conditions, three irrigations were applied according to crop requirements. First irrigation was applied three weeks after emergence, second at flowering and third at pod formation. While in pot trial, irrigation was applied when required as per weather conditions and critical crop growth stages. Crop was harvested manually when $90 \%$ of pods ripened and turned brown. Harvesting was done on $13^{\text {th }}$ of July 2012. Harvested crop was sun dried for four days in the field and then threshed manually at about $12-14 \%$ grain moisture level.

\section{Experimental Treatments}

Both $\mathrm{Zn}$ and B in the form of zinc sulphate (21\%) and boric acid (17\%), as per treatment were applied at the time of sowing as soil application by side dressing method both in field and pot experiment. Treatment combinations were included viz; $\mathrm{B}_{0} \mathrm{Zn}_{0}, \mathrm{~B}_{0} \mathrm{Zn}_{2}, \mathrm{~B}_{0} \mathrm{Zn}_{4}$, $\mathrm{B}_{2} \mathrm{Zn}_{0}, \mathrm{~B}_{2} \mathrm{Zn}_{2}, \mathrm{~B}_{2} \mathrm{Zn}_{4}, \mathrm{~B}_{4} \mathrm{Zn}_{0}, \mathrm{~B}_{4} \mathrm{Zn}_{2}, \mathrm{~B}_{4} \mathrm{Zn}_{4}$.

\section{Data Collection}

Data regarding plant height, plant population, number of pod bearing branches per plant, number of pods per plant, number of seeds per pod and pod length were collected from ten plants and average was taken to calculate the measures for total experimental area. For determination of root nodules, three plants per plot with roots intact were pulled out at random by digging at flowering stage; their roots were soaked in water and then washed to clean them. Nodules were counted manually and their average was calculated. Similar procedure was followed to determine the number of nodules for plants in pots. 
Five samples of 100 -seeds were used from each plot at random, then they were weighed and their average was used to calculate 1000 -seed weight by unitary method. In pot experiment all seeds were taken, weighed and averaged then unitary method was used to calculate 100 seed weight. The seed produce per plot was taken after threshing the crop manually and then it was weighed and converted into $\mathrm{kg} / \mathrm{ha}$. For pot experiment, the seed produced from three plants was taken, weighed and averaged. It was taken in $\mathrm{g} / \mathrm{plant}$. At maturity, biomass yield $\left(\mathrm{kg} \mathrm{ha}^{-1}\right)$ was calculated by harvesting the plants manually from each plot and were dried for ten days under sunlight, tied into bundles and weighed by using a spring balance.. Similar procedure was followed to calculate the biomass yield for pot trial. The harvest indices were computed by using the ratio of seed yield to biological yield and then multiplied by 100 , in both trials. Biochemical Analysis

For protein content (\%), first $\mathrm{N}$ concentration was determined by using the Kjeldhal apparatus method (Bremner and Mulvaney, 1982). As $1 \mathrm{~g}$ of oven dried plant material was digested by Kjeldahl's method by adding 20 mL of concentrated $\mathrm{H}_{2} \mathrm{SO}_{4}$ and $5 \mathrm{~g}$ of digestion mixture $\left(\mathrm{K}_{2} \mathrm{SO}_{4}: \mathrm{FeSO}_{4}: \mathrm{CuSO}_{4}\right.$ 85:10:5). After digestion, distillation was carried out by taking $10 \mathrm{~mL}$ of aliquot by using Markam Still Apparatus. Evolved $\mathrm{NH}_{3}$ gas was absorbed in receiver containing mixed indicator $(4 \% 10 \mathrm{~mL}$ boric acid and methyl red). After completion of distillation, contents of receiver were titrated against $0.1 \mathrm{~N} \mathrm{H}_{2} \mathrm{SO}_{4}$ (Jackson, 1962) from golden yellow to purple end point and then $\mathrm{N}$ was obtained by using the formula given below (Van Schouwenberg and Walinge, 1973):

$$
\% \mathrm{~N}=\frac{0.0014 \times(\mathrm{mL} \text { of titrant for blank }-\mathrm{mL} \text { of titrant for sample }) \times 0.01 \mathrm{~N} \text { of acid } \times(\text { dilution factor if any })}{\text { Weight of the sample }(\mathrm{g}) \times 10 \mathrm{~mL} \text { used for distillation }} \times 100
$$

The protein contents were then computed by using the factor.

Crude protein $\%=$ nitrogen $\% \times 6.25$

\section{Economic and Statistical Analysis}

For economic analysis, CIMMYT (1998) methodology was used. Gross field benefits represent the income obtained from the crop yield. Gross investment was determined in Rs./ha by calculating every treatments' cost of production. Net field benefits (Rs./ha) gross investment was subtracted from the gross field benefits. Benefit cost ratio is a ratio of gross income to the total cost. All the data collected was statistically analyzed using statistically by using Fisher's analysis of variance technique and differences among treatments' means were compared using least significant difference (LSD) test at 5\% probability level (Steel et al., 1997). Statistical software Statistix 8.1 was used for computing results.

\section{RESULTS AND DISCUSSION \\ Phenology and Yield Attributes}

Effect of soil applied $\mathrm{Zn}$ and B fertilizers was appeared non-significant $(\mathrm{P}>0.05)$ on plant population (Table 3$)$. Data showed that plant height, yield and yield related attributes of both field and pot trials were improved under combined $\mathrm{Zn}$ and $\mathrm{B}$ treatments as compared to control and where both micronutrients were applied separately (Table $3 \& 4$ ). Treatment $\mathrm{B}_{0} \mathrm{Zn}_{4}$ helped to increase plant height and pod length in field trials while
$\mathrm{B}_{2} \mathrm{Zn}_{4}$ positively affected plant height, number of pods per plant, pod length, number of nodules and seed yield in both field and pot trials (Table 3 \& 4). Moreover, $\mathrm{B}_{2} \mathrm{Zn}_{4}$ treatment also improved the number of pod bearing branches per plant and number of seeds per pod in field trial as compared to control and other set of treatments (Table 3). Number of pods per plant, number of nodules per plant and seed weight also performed best under $\mathrm{B}_{2} \mathrm{Zn}_{2}$ treatment when applied under field conditions. The application of $\mathrm{B}_{4} \mathrm{Zn}_{0}, \mathrm{~B}_{4} \mathrm{Zn}_{2}$, and $\mathrm{B}_{4} \mathrm{Zn}_{4}$ treatments depicted negative effects on yield related attributes in both field and pot trials.

Among some imperative factors that contribute to final yield, plant population is one of them. An optimal plant population is measured as the base to get increased seed yield. Generally, more number of plants, better will be the crop yield. The non-significant behavior might be due to the fact that row to row distance was maintained at time of sowing and homogenous plant to plant distance was also obtained by thinning. Non-significant plant population was due to the fact that it was neither affected by the foliar nor soil applied nutrients at time of germination. Similarly, the unobvious effect of nutrients on the plant population $\left(\mathrm{m}^{-2}\right)$ was witnessed by Bertolini et al. (1982), Lee and Estes, (1982) and Dordas, (2006). 
Table 3. Effect of zinc sulphate and boric acid application on agronomic traits of mungbean.

\begin{tabular}{|c|c|c|c|c|c|c|c|c|c|c|c|c|}
\hline \multirow[t]{2}{*}{ Treatments } & \multicolumn{2}{|c|}{$\begin{array}{c}\text { Plant population at } \\
\text { harvest }\left(\mathrm{m}^{-2}\right)\end{array}$} & \multicolumn{2}{|c|}{$\begin{array}{l}\text { Plant height at } \\
\text { maturity }(\mathrm{cm})\end{array}$} & \multicolumn{2}{|c|}{$\begin{array}{l}\text { Number of pod bearing } \\
\text { branches per plant }\end{array}$} & \multicolumn{2}{|c|}{$\begin{array}{c}\text { Number of pods per } \\
\text { plant }\end{array}$} & \multicolumn{2}{|c|}{ Pod length $(\mathrm{cm})$} & \multicolumn{2}{|c|}{$\begin{array}{c}\text { Number of seeds } \\
\text { per pod }\end{array}$} \\
\hline & Field Trial & Pot Trial & Field Trial & Pot Trial & Field Trial & Pot Trial & Field Trial & Pot Trial & Field Trial & Pot Trial & Field Trial & Pot Trial \\
\hline$\overline{\mathrm{B}_{0} \mathrm{Zn}_{0}}$ & 25.5 & - & $44.76 \mathrm{~d}$ & $18.72 \mathrm{e}$ & $4.8 \mathrm{f}$ & $3.66 \mathrm{f}$ & $25.62 \mathrm{~d}$ & $10.66 \mathrm{e}$ & $5.96 \mathrm{~d}$ & $4.6 \mathrm{f}$ & $3.83 \mathrm{e}$ & $6.04 \mathrm{de}$ \\
\hline $\mathrm{B}_{0} \mathrm{Zn}_{2}$ & 28.99 & - & $51.13 \mathrm{c}$ & $24.68 \mathrm{~b}$ & $6.86 \mathrm{c}$ & $7.28 \mathrm{c}$ & $32.6 \mathrm{~b}$ & $17.54 \mathrm{~b}$ & $7.32 \mathrm{c}$ & $6.36 \mathrm{~cd}$ & $6.13 \mathrm{bc}$ & $5.74 \mathrm{e}$ \\
\hline $\mathrm{B}_{0} \mathrm{Zn}_{4}$ & 31.31 & - & $60.66 \mathrm{a}$ & $23.4 \mathrm{bc}$ & $7.76 \mathrm{~b}$ & $5.52 \mathrm{e}$ & $32.1 \mathrm{~b}$ & $14.37 \mathrm{~cd}$ & $10.17 \mathrm{a}$ & $5.88 \mathrm{de}$ & $6.5 \mathrm{~b}$ & $6.88 \mathrm{c}$ \\
\hline $\mathrm{B}_{2} \mathrm{Zn}_{0}$ & 30.43 & - & $53.33 \mathrm{bc}$ & $22.66 \mathrm{~cd}$ & $6.5 \mathrm{~cd}$ & $6.56 \mathrm{~d}$ & $29.83 \mathrm{bc}$ & $13.81 \mathrm{~d}$ & $6 \mathrm{~d}$ & $7.18 \mathrm{~b}$ & $6.5 \mathrm{~b}$ & $6.74 \mathrm{c}$ \\
\hline $\mathrm{B}_{2} \mathrm{Zn}_{2}$ & 29.97 & - & $51.83 \mathrm{bc}$ & $23.6 \mathrm{bc}$ & $5.76 \mathrm{de}$ & $6.75 \mathrm{~cd}$ & $37.42 \mathrm{a}$ & $15.49 \mathrm{c}$ & $8.62 \mathrm{~b}$ & $6.82 \mathrm{bc}$ & $6.06 \mathrm{bc}$ & $7.55 \mathrm{~b}$ \\
\hline $\mathrm{B}_{2} \mathrm{Zn}_{4}$ & 31.97 & - & $56.8 \mathrm{ab}$ & $27 \mathrm{a}$ & $9.03 \mathrm{a}$ & $6.64 \mathrm{~d}$ & $38.78 \mathrm{a}$ & $20.66 \mathrm{a}$ & $9.28 \mathrm{ab}$ & $10.18 \mathrm{a}$ & $8.36 \mathrm{a}$ & $8.04 \mathrm{~b}$ \\
\hline $\mathrm{B}_{4} \mathrm{Zn}_{0}$ & 28.54 & - & $51.53 \mathrm{bc}$ & $24.98 \mathrm{~b}$ & $5.23 \mathrm{ef}$ & $8.3 \mathrm{~b}$ & $27.6 \mathrm{~cd}$ & $13.31 \mathrm{~d}$ & $6.34 \mathrm{~d}$ & $7.32 \mathrm{~b}$ & $5.1 \mathrm{~d}$ & $4.68 \mathrm{f}$ \\
\hline $\mathrm{B}_{4} \mathrm{Zn}_{2}$ & 29.1 & - & $47.99 \mathrm{~cd}$ & $21.36 \mathrm{~d}$ & $6.7 \mathrm{c}$ & $9.76 \mathrm{a}$ & $29.96 \mathrm{bc}$ & $11.48 \mathrm{e}$ & $6.54 \mathrm{~cd}$ & $5.48 \mathrm{e}$ & $5.56 \mathrm{~cd}$ & $9.46 \mathrm{a}$ \\
\hline $\mathrm{B}_{4} \mathrm{Zn}_{4}$ & 29.88 & - & $52.53 \mathrm{bc}$ & $23.94 \mathrm{bc}$ & $5.3 \mathrm{ef}$ & $5.37 \mathrm{e}$ & $32.26 \mathrm{~b}$ & $15.57 \mathrm{c}$ & $7.44 \mathrm{c}$ & $6.38 \mathrm{~cd}$ & $5.23 \mathrm{~cd}$ & $6.62 \mathrm{~cd}$ \\
\hline LSD & NS & - & 5.528 & 1.889 & 0.754 & 0.597 & 3.649 & 1.253 & 0.977 & 0.317 & 0.912 & 0.643 \\
\hline
\end{tabular}

NS = Non-significant, LSD = Least significant difference

Table 4. Effect of zinc sulphate and boric acid application on agronomic traits and yield components of mungbean

\begin{tabular}{|c|c|c|c|c|c|c|c|c|c|c|c|c|}
\hline \multirow{2}{*}{ Treatments } & \multicolumn{2}{|c|}{$\begin{array}{c}\text { Number of nodules } \\
\text { per plant }\end{array}$} & \multicolumn{2}{|c|}{ Seed weight (g) } & \multicolumn{2}{|c|}{ Seed yield } & \multicolumn{2}{|c|}{ Biological yield } & \multicolumn{2}{|c|}{ Harvest index (\%) } & \multicolumn{2}{|c|}{ Protein content (\%) } \\
\hline & $\begin{array}{c}\text { Field } \\
\text { Trial }\end{array}$ & Pot Trial & $\begin{array}{l}\text { Field Trial } \\
\text { (1000-Seed) }\end{array}$ & $\begin{array}{l}\text { Pot Trial } \\
\text { (100-Seed) }\end{array}$ & $\begin{array}{l}\text { Field Trial } \\
\left(\mathrm{t} \mathrm{ha}^{-1}\right)\end{array}$ & $\begin{array}{l}\text { Pot Trial } \\
(\mathrm{g} / \mathrm{plant})\end{array}$ & $\begin{array}{l}\text { Field Trial } \\
\left(\mathrm{t} \mathrm{ha}^{-1}\right)\end{array}$ & $\begin{array}{l}\text { Pot Trial } \\
(\mathrm{g} / \text { plant })\end{array}$ & Field Trial & Pot Trial & Field Trial & Pot Trial \\
\hline$\overline{\mathrm{B}_{0} \mathrm{Zn}_{0}}$ & $5.33 \mathrm{~d}$ & $4.86 \mathrm{~g}$ & $53.66 \mathrm{de}$ & $3.9 \mathrm{~d}$ & $1047 \mathrm{e}$ & $3.9 \mathrm{~d}$ & 4715 & $10.03 \mathrm{~d}$ & 22.22 & - & 20.93 & $14.96 \mathrm{e}$ \\
\hline $\mathrm{B}_{0} \mathrm{Zn}_{2}$ & $10.33 \mathrm{~b}$ & $8.06 \mathrm{~d}$ & $56 \mathrm{~cd}$ & $5.08 \mathrm{c}$ & $1223 \mathrm{bcd}$ & $4.57 \mathrm{c}$ & 4991 & $10.88 \mathrm{~cd}$ & 24.57 & - & 20.43 & $18.78 \mathrm{~d}$ \\
\hline $\mathrm{B}_{0} \mathrm{Zn}_{4}$ & $6.1 \mathrm{~d}$ & $5.9 \mathrm{f}$ & $64 \mathrm{ab}$ & $5.29 \mathrm{bc}$ & 1146 cde & $6.32 \mathrm{a}$ & 5051 & $11.5 \mathrm{bc}$ & 22.62 & - & 19.43 & $20.14 \mathrm{c}$ \\
\hline $\mathrm{B}_{2} \mathrm{Zn}_{0}$ & $10.56 \mathrm{~b}$ & $6.72 \mathrm{e}$ & $55.33 \mathrm{~cd}$ & $5.3 \mathrm{bc}$ & $1207 \mathrm{bcde}$ & $5.38 \mathrm{~b}$ & 5146 & $10.97 \mathrm{c}$ & 23.44 & - & 20.8 & $20.08 \mathrm{c}$ \\
\hline $\mathrm{B}_{2} \mathrm{Zn}_{2}$ & $13.43 \mathrm{a}$ & $9.35 \mathrm{a}$ & $68.33 \mathrm{a}$ & $6.19 \mathrm{a}$ & $1326 \mathrm{ab}$ & $5.45 \mathrm{~b}$ & 5177 & $13.86 \mathrm{a}$ & 25.68 & - & 21.16 & $19.96 \mathrm{c}$ \\
\hline $\mathrm{B}_{2} \mathrm{Zn}_{4}$ & $12.56 \mathrm{a}$ & $9 \mathrm{ab}$ & $57.33 \mathrm{~cd}$ & $5.31 \mathrm{bc}$ & $1402 \mathrm{a}$ & $6.42 \mathrm{a}$ & 5383 & $11.88 \mathrm{~b}$ & 26.06 & - & 22.1 & $22.08 \mathrm{a}$ \\
\hline $\mathrm{B}_{4} \mathrm{Zn}_{0}$ & $11.2 \mathrm{~b}$ & 6.4 ef & $55 \mathrm{~cd}$ & $5.12 \mathrm{bc}$ & $1083 \mathrm{de}$ & $5.54 \mathrm{~b}$ & 4985 & $11.73 \mathrm{bc}$ & 21.75 & - & 20.86 & $19.48 \mathrm{~cd}$ \\
\hline $\mathrm{B}_{4} \mathrm{Zn}_{2}$ & $10.13 \mathrm{~b}$ & $8.68 \mathrm{bc}$ & $61 \mathrm{bc}$ & $5.58 \mathrm{~b}$ & $1262 \mathrm{abc}$ & $5.25 \mathrm{~b}$ & 5259 & $13.13 \mathrm{a}$ & 23.98 & - & 20.46 & $21.04 \mathrm{~b}$ \\
\hline $\mathrm{B}_{4} \mathrm{Zn}_{4}$ & $8.53 \mathrm{c}$ & $8.36 \mathrm{~cd}$ & $48.33 \mathrm{e}$ & $5.13 \mathrm{bc}$ & $1288 \mathrm{bc}$ & $5.11 \mathrm{bc}$ & 4932 & $11.21 \mathrm{bc}$ & 26.25 & - & 17.16 & $19.5 \mathrm{~cd}$ \\
\hline LSD & 1.213 & 0.552 & 6.444 & 0.494 & 169.2 & 0.602 & NS & 0.892 & NS & - & NS & 0.507 \\
\hline
\end{tabular}

NS = Non-significant, LSD = Least significant difference. 
Plant height reveals vegetative growth behavior of crop in response to nutrient inputs. This phenotypic trait is a function of combined effects of inherited makeup of plant, soil nutrient status, seed vigor and environmental situations to which plant is exposed during its whole growth period. More plant height specifies more vegetative growth and vice versa. Boron is positively involved in metabolism and increases the photosynthetic rates and often results in increased plant height at maturity (Kaisher et al., 2010) and application of zinc significantly manifested better growth and plant height of mungbean (Gobarah et al., 2006) which proved the result of this study.

Simultaneous effects of increased vegetative growth were observed on different stages of crop as both number of pod bearing branches and pods number were found responsive to interactive relation of soil applied $\mathrm{Zn}$ and B. Almost similar results were observed by Ali and Mishra, (2001) who claimed that B use increased number of pod bearing branches per plant. Our results were in line to the observations of Kassab, (2005) as his results depicted better growth, photosynthesis and pod formation in beans under optimum application of Zn. Besides, Verma et al. (2011) stated that pods count per plant in mungbean was considerably increased after B and sulphur (S) use. Increased pods count per plant might be attributed to $B$ supply to plants which results in more flowers and pollen grain formation, thus in turn increase pod number. In addition to micro-nutrient application, similar findings were given by Tripathi et al. (2012) after inoculating mungbean seeds with Rhizobia.

Pod length, pods count per plant and seeds per pod also determine the yield performance in legumes. These parameters are interlinked with final seed yield of the crop. As pod length increases, seeds per pod also increase linearly and same is the case with pods count per plant and vice versa. In the current study, provision of optimum plant nutrition in the form of $\mathrm{Zn}$ and $\mathrm{B}$ ensured maximum number of pods count and seeds per pod that in turn may enhance the seed yield. It may be due to fact as stated by Gentry, (2010) that applying optimum dose of $\mathrm{Zn}$ enhanced pod length of mungbean. Onaran and Yucedag, (2013) documented that B application showed a significant effect on pod length and B content of grains however, this effect varied with B concentrations used and plant species. Similar results were recorded by Kaisher et al. (2010) regarding the number of seeds per pod in green gram after B use.
Both grain weight links and it's are interlinked as bold grains brings out higher yields. The study results indicated that $\mathrm{Zn}$ and $\mathrm{B}$ application depicted prominent effects on seed weight both in pot and field trials including their interaction effects. Possible reasoning behind this effect could be the B supply, thus improves the cell division, sugar and starch formation which enhances the seed size and thereby seed weight (Ahmad et al., 2007). Other study also revealed that $\mathrm{Zn}$ application results in higher plant growth including 1000-seed weight in cowpea crop (Khourgami and Fard, 2012).

\section{Seed and Biomass Yield}

Seed yield is estimated as the efficacy of any treatment for grain production which is the ultimate outcome of crops. This attribute is believed to be upheld by various external (environmental) and internal (i.e. yield related crop attributes) factors and any deviation in these factors is assessed for variation in final yield. Besides, grain yield is a result of cumulative effects of varietal potential and use of agronomic practices. Significant results of various levels of $\mathrm{B}$ and $\mathrm{Zn}$ use affected the grain yield during this study. Other researchers also found that application of B gave maximum expected seed yield in green gram (Mondal et al., 2003; Prajapat et al., 2012; Tripathi et al., 2012). They justified their findings in a sense that $B$ makes the stigma receptive and sticky, enhance pollen grain fertility, pollination and ensures better fruit setting, reducing flower abortion and thus maintains maximum grains number per pod. Moreover, studies proved that application of $\mathrm{Zn}, \mathrm{B}$ and manganese $(\mathrm{Mn})$ alone or in combinations appear to influence the distinctive role in increasing the seed yield in beans thus proved the results of current study.

The total biomass produced by crop consists of seed and straw yield and is a function of both the genetic makeup of plant and environmental situation in which plants are grown. Along with this is the harvest index, which is estimated as physiological efficiency and capability of the crop for transforming total dry matter in to economic yield. In the present study, phenology related attributes of the crop has improved after $\mathrm{Zn}$ and $\mathrm{B}$ use in combination thus showing simultaneous effects on biomass and grain yield. Similarly, Jat et al. (2012) and Tripathi et al. (2012) observed considerable effects regarding crop growth and biomass production after $\mathrm{Zn}$, $S$ and rhizobial inoculation in mungbean. However, our study results depicted non-significant effects on harvest index of crop after B and $\mathrm{Zn}$ use regarding their individual 
and interaction. This might be due to increase in both biomass and seed yields which have caused nonsignificant variations in harvest indices of plants.

\section{Roots Nodulation}

Additionally, an in indirect parameter responsible for increased biomass and seed yield of legumes is their ability for $\mathrm{N}$-fixation in plant roots from atmosphere. More the number of nodules greater will be nitrogen fixation and vice versa. While, there exists a direct relationship between $\mathrm{N}$-fixation and protein synthesis by mungbean plants. The results indicated above showed that use of $\mathrm{B}$ and $\mathrm{Zn}$ in combinations remarkably accelerated the rate of root nodulation and resultantly the protein contents in grains. Inoculation with rhizobia and micro-nutrients application resulted in higher nodule numbers and nodule dry weight (Tripathi et al., 2012). Similar findings were witnessed by Salwa et al. (2011) in terms of limiting growth, symbiosis and lesser nodulation under $\mathrm{Zn}$ and iron deficiency in beans. While, improved seed protein content in mungbean + sesame intercropping were obtained after application of $\mathrm{S}$ as it plays an important role in protein synthesis (Prajapat et al., 2012).

\section{Economic Returns}

Economic analysis is very important tool for basic determination of net benefits. It is clear from data that both net income and benefit cost ratio were achieved maximum with treatment of $\mathrm{B}_{2} \mathrm{Zn}_{4}$ but minimum values were recorded in control.

\section{CONCLUSIONS}

A precise calculation of application rates regarding micronutrient application necessitates to best management practices. The findings of current study made clear that crop phenology, yield and yield related attributes of mungbean were responsive to variable rates of B and Zn. Although, the higher rates of applied treatments provide yield benefits but did not seem economical for both field and pot experiments. However, keeping in view the efficacy of foliar based micronutrient application; further studies are advised to be conducted for mungbean.

\section{AUTHORS CONTRIBUTION}

MFS and MAW planned the trials. AM has worked to conduct the planned experiments, gathered data, performed nutrient and biochemical analysis while MTS helped to conduct the biochemical analysis in the laboratory. AM also performed statistical analysis of the collected data while AM MTS mutually completed the write-up of the manuscript.

\section{ACKNOWLEDGEMENTS}

The authors are grateful to the field staff for their support during the conduct of experiment, management and analytical laboratory of the Department of Agronomy, University of Agriculture Faisalabad, Pakistan for needful guidance in post-harvest biochemical analysis.

\section{CONFLICT OF INTEREST}

The author(s) declare(s) that there is no conflict of interests regarding the publication of this article.

\section{REFERENCES}

Afzal, M. A., M. A. Bakr, A. Hamid, M.M. Haque and M. S. Aktar. 2004. Mungbean in Bangladesh. Lentil blackgram and mungbean development pilot project. Pulses Research Centre, BARI, Gazipur1701, Publication No. 23 p: 60.

Ahmad, S., I. S. Fazli, A. Jamal, M. Iqbal and M. Z. Abdin. 2007. Interactive effect of sulphur and nitrogen on nitrate reductase and ATP-Sulphurylase activities in relation to seed yield from Psoralea corylifolia L. Journal of Plant Biology, 50: 351-357.

Ali, M. and Abedullah. 1998. Supply demand and policy environment for pulses in Pakistan. Pakistan Development Review. pp: 35-52.

Ali, M. and J. P. Mishra. 2001. Effect of foliar nutrient of B and Mo on chickpea. Indian Journal of Pulse Research, 14: 41-43.

Alloway, B. J. 2004. Zinc in soils and crop nutrition. Areas of the World with zinc deficiency problems. Available online at: http://www.zinccrops.org/Crops/Alloway- all.php.

Alloway, B. J. 2008. Zinc in soils and crop nutrition. Second ed. International Zinc Association (IZA) and International Fertilizer Association (IFA), Brussels, Belgium and Paris, France.

Batjes, N. H. 1997. A world data set of derived soil properties by FAO- UNESCO soil unit for global modeling. Soil Use Manage. 13: 9-16.

Bertolini, M., F. Monguzzi and S. Cittar. 1982. Una sindroma da freddoaffidi-virus: rilievi sulla resistenza di ibridi commerciali, line pure e ibridi a formulazione aperta di maYs. L, informatore Agrariao. 8: 19355-19357. 
Bremner, R. M. and C. S. Mulvaney. 1982. Nitrogen total. P. 595-624. In A.L. Page (ed.), Methods of soil analysis, Agron. No.9. Madison, WI, USA.

Broadley, M. R., P. Brown, I. Cakmak, Z. Rengel and F. Zhao. 2012. Function of nutrients: Micronutrients. In: Marschner's Mineral Nutrition of Higher Plants, 3rd edition. P. Marschner (ed.). Academic Press, London, UK. pp. 208-265.

Camacho-Cristobal, J. J., J. Rexach and A. Gonzaleg-Fontes. 2008. Boron in plants: Deficiency and toxicity. Journal of Integrative Plant Biology, 50: 12471255.

CIMMYT. 1998. An Economic Training handbook. Economic Programme, CIMMYT, Mexico.

Dordas, C. 2006. Foliar boron application improves seed set, seed yield and seed quality of alfalfa. Agronomy Journal, 98: 907-13.

Gentry, J. 2010. Mungbean management guide. 2nd edn. Pulse Australia, Australian Mungbean Association, Queensland Government, http://mungbean.org.au/bestmanagementguide.html.

Gobarah, E. Mirvat, M. H. Mohamed and M. M. Tawfik. 2006. Effect of phosphorus fertilizer and foliar spraying with zinc on growth, yield and quality of groundnut under reclaimed sandy soil. Journal of Applied and Scientific Research, 2: 491-496.

Government of Pakistan. 2020. Economic survey of Pakistan 2019-20. Ministry of Food, Agriculture and Livestock, Finance division, Economic advisor wing, Islamabad, Pakistan pp: 17

Gupta, U. C. 2007. Boron. pp. 241-277, In: A. V. Barker and D. J. Pilbeam (eds.). Handbook of Plant Nutrition. CRC Press, Taylor and Francis, USA.

Hafeez, B., Y. M. Khanif and M. Saleem. 2013. Role of Zinc in Plant Nutrition- A Review. American Journal of Experimental Agriculture, 3: 374-391.

Hotz, C. and K. H. Brown. 2004. Assessment of the risk of zinc deficiency in populations and options for its control. Food Nutrition. Bulletin, 25: 94-204.

Jackson, M. L. 1962. Soil chemical analysis. Printce Hall Inc. Englewood Cliffs, New Jersey, USA.

Jat, J. S., B. S. Rathore and M. G. Chaudhary. 2012. Effect of sulphur and zinc on growth, chlorophyll content, yield attributes and yields of mustard (Brassica juncea) on clay loam soil of Rajasthan. AGRES-An International e-Journal. pp: 42-52.

Kaisher, M. S., M. A. Rahman, M. H. A. Amin, A. S. M.
Amanullah and A. S. M. Ahsanullah. 2010. Effects of sulphur and boron on the seed yield and protein content of mungbean. Bangladesh Research Publication Journal, 3: 1181-1186.

Kassab, O.M. 2005. Soil moisture stress and micronutrients application effects on growth and yield of mungbean plants. Journal of Agricultural Science, 30: 247-256.

Khattak, G. S. S, M. Ashraf, T. Elahi and G. Abbas. 2003. Selection for large seed size at the seedling stage in mungbean (Vigna radiata L.). Breeding Science, 53: 141-143.

Khattak, G. S. S., M. Ashraf and R. Zamir. 2004. Gene action for synchrony in pod maturity and indeterminate growth habit in mungbean (Vigna radiata L.) Pakistan Journal of Botany, 36: 589-594.

Khourgami, A. and S. R. Fard. 2012. The effect of zinc application and plant density on yield and yield components of green gram. Annals of Biological Research, 3: 4172-4178.

Lee, S. S. and G. O. Estes. 1982. Corn physiology in short season and low temperature environments. Agronomy Journal, 74: 325-331.

Mahmood, A. and M. Athar, 2008. Cross inoculation studies: Response of Vigna mungo to inoculation with rhizobia from tree legumes growing under arid Environment. International Journal of Environmental Science and Technology, 5: 135139.

Mandal, S., Mandal, M., Das, A., Pati, B. and Ghosh, A., 2009. Stimulation of indoleacetic acid production in a Rhizobium isolate of Vigna mungo by root nodule phenolic acids. Archives of Microbiology, 191: pp: 389.

Mondal, S. S., A. Ghosh, S. Biswajti and D. Acharya. 2003. Studies on the effect of potassium, sulphur and irrigation on growth and yield of green gram. Journal of Interacademicia, 7: 273-277.

Nasiri, M., M. Khalatbari and H. A. Farahani. 2011. Znfoliar application influence on quality and quantity features in Phaseolous vulgaris under different levels of $\mathrm{N}$ and $\mathrm{K}$ fertilizers. Advances in Environmental Biology, 5: 839-847.

Nawab, K., P. Shah, M. Arif, A. Ullah, M.A. Khan, A. Mateen and K. Ali. 2011. Effect of cropping patterns, farm yard manure, $\mathrm{K}$ and $\mathrm{ZN}$ on wheat growth and grain yield. Sarhad Journal of Agriculture, 27: 371-375.

Onaran, M. A. and C. Yucedag. 2013. The effects on 
germination and growth of bean and chickpea of boron waste. Journal of Science, 8: 48-53.

Osendarp, S. I., C. E. West and R. E. Black. 2003. The need for maternal zinc supplementation in developing countries: an unresolved issue. Journal of Nutrition, 133: 817-827.

Prajapat, K., A. C. Shivran, G. L. Choudhary and H. R. Choudhary. 2012. Influence of planting pattern and sulphur on mungbean and sesame intercropping under semi-arid region of Rajasthan. Indian Journal of Agronomy, 57: 89.

Quddus, M. A., M. H. Rashid, M. A. Hossain and H. M. Naser. 2011. Effect of zinc and boron on yield and yield contributing characters of mungbean in low ganges river floodplain soil at Madaripur, Bangladesh. Bangladesh Journal of Agricultural Research, 36: 75-85.

Raj, S. 1985. An Introduction to Physiology of Field Crops. Oxford and IBH Publishing Co., New Delhi pp: 9497.

Rani, S., H. Shah, U. Farooq and B. Rehman. 2014. Supply, demand and policy environment for pulses in Pakistan. Pakistan Journal of Agricultural Research, 27.

Rashid, A. and J. Ryan. 2008. Micronutrient constraints to crop production in the Near East: Potential significance and management strategies. In: Micronutrient Deficiencies in Global Crop Production. B. J. Alloway (ed.). Springer, Dordrecht, Netherlands. pp. 149-180.

Reid, R. 2007. Identification of boron transporter genes likely to be responsible for tolerance to boron toxicity in wheat and barley. Plant and Cell Physiology, 48: 1673-1678.

Ross, J. R., N. A. Slaton, K. R. Brye and R. E. Delong. 2006. Boron fertilization influences on soybean yield and leaf and seed born concentration. Agronomy Journal, 98: 198-205.

Salwa, A. I. E., M. B. Taha and M. A. M. Abdalla. 2011. Amendment of soil fertility and augmentation of quantity and quality of soybean crop by using phosphorus and micronutrients. International
Journal of Academic Research, 3: 10-127.

Sandberg, A. S. 2002. Bioavailability of minerals in legumes. British Journal of Nutrition, 88: 281-285.

Sasode, D. S. 2008. Response of green gram (Vigna radiata L. Wilczek) to fertility levels and sulphur sources application. Agricultural Science Digest, 28: 18-21.

Steel, R. G. D., J. H. Torrie and D. A. Dickey. 1997. Principles and Procedures of Statistics. A biometrical approach. $3^{\text {rd }}$ Ed., McGraw Hill Book Co. New York, USA. Pp. 352-358.

Tripathi, P. K., M. K. Singh, J. P. Singh and O. N. Singh. 2012. Effect of rhizobial straines and micronutrients nutrition on mungbean (Vigna radiata L.) cultivars under dry-land agro-ecosystem of Indo-Gangetic plain. African Journal of Agricultural Research, 7: 34-42.

Usman, F., A. Hassan and A. Ahmad. 2007. Arterial ischemic stroke with protein deficiency in Pakistan. Rawal Medical Journal, 32: 205-209.

Vallee, B. L. and D. S. Auld. 1990. Zinc coordination, function and structure of zinc enzymes and other proteins. Biochemistry, 29: 5647-5659.

Vallee, B. L. and K. H. Falchuk. 1993. The biochemical basis of zinc physiology. Physiological, Reviews, 73: 79118.

Van Schouwenberg, J.C.H. and I. Walinge. 1973. Methods of analysis for plant material. Agric. Univ. Wageningen, The Netherlands.

Verma, J. P., V. Singh and J. Yadav. 2011. Effect of copper sulphate and borax on seed germination, plant growth and peroxidase activity of mungbean (Vigna radiata L.) International Journal of Botany, 7: 200-204.

World Health Organization, (WHO). 2002. World Health Report 2002: Reducing Risks, Promoting Healthy Life. WHO, Geneva, Switzerland.

Yin Z, Guo W, Xiao H, Liang J, Hao X, Dong N, et al. 2018. Nitrogen, phosphorus, and potassium fertilization to achieve expected yield and improve yield components of mung bean. PLoS ONE 13(10): e0206285.

https://doi.org/10.1371/journal.pone.0206285. 
Publisher's note: EScience Press remains neutral with regard to jurisdictional claims in published maps and institutional affiliations.

(우요

Open Access This article is licensed under a Creative Commons Attribution 4.0 International License, which permits use, sharing, adaptation, distribution and reproduction in any medium or format, as long as you give appropriate credit to the original author(s) and the source, provide a link to the Creative Commons license and indicate if changes were made. The images or other third-party material in this article are included in the article's Creative Commons license, unless indicated otherwise in a credit line to the material. If material is not included in the article's Creative Commons license and your intended use is not permitted by statutory regulation or exceeds the permitted use, you will need to obtain permission directly from the copyright holder. To view a copy of this license, visit http://creativecommons.org/licenses/by/4.0/.

(c) The Author(s) 2020. 